\title{
ASIS/NAPS Depository and Reproduction Service
}

ASIS/NAPS, c/o Microfiche Publications, P.O. Box 3513, Grand Central Station, New York, NY 10163-3513

The American Society for Information Science (ASIS) National Auxiliary Publications Service (NAPS) provides a repository for, and furnishes on demand, copies of materials that are adjunct to papers published in scholarly or technical journals, but that would require too many journal pages to publish in their entirety. The availability of the deposited material is announced at the time that the relevant journal article is published, so that readers of the article may order copies. Materials are furnished in either microfiche or hard copy (photocopy). 